\title{
Influence of Marital Status on Teachers' Self-Efficacy in Secondary Schools of Kisumu County, Kenya
}

\author{
Sylvester J. 0. Odanga \\ PhD Student, Jaramogi Oginga Odinga University of Science and Technology \\ ${ }^{*}$ Dr Peter J.0. Aloka \\ Department of Psychology, Jaramogi Oginga Odinga University of Science and Technology \\ P.O. BOX 210, Bondo, 40601, Kenya; jairopeteraloka@yahoo.com \\ Dr. Pamela Raburu \\ Head of Department of Psychology, Jaramogi Oginga Odinga University of Science and Technology
}

Doi:10.5901/ajis.2015.v4n3p115

\begin{abstract}
The study investigated the influence of marital status on teachers' self-efficacy in public secondary schools of Kisumu County, Kenya. Concurrent Triangulation Design was adopted to collect quantitative and qualitative data from samples of 327 students and 12 teachers. The interview schedule and questionnaire were piloted with 2 and 33 teachers respectively, who did not participate in the survey. Piloting helped to clarify the test items, determine construct validity $(r=0.564$ for items expected to have similar responses and $r=-0.325$ for items expected to have different responses) and two experts in Educational Psychology established face validity of the research instruments. Internal reliability was established at Cronbach's $\alpha=0.9976$. Multivariate Analysis of Variance (MANOVA) was used to analyze data from questionnaire. The quantitative findings revealed that marital status had no statistically significant influence on teachers' self-efficacy while the qualitative findings revealed that marital status had an influence on teachers' self-efficacy. The study recommends the employment of counsellors in schools to help teachers to deal with psychosocial and domestic issues.
\end{abstract}

Keywords: self-efficacy; teachers; marital status; secondary school.

\section{Introduction}

Teachers' self-efficacy determines levels of effectiveness, innovativeness and persistence among teachers (Protheroe, 2008; Klassen \& Chiu, 2010). Teachers with a stronger sense of efficacy are better in planning, innovation, resilience, acceptance of students and achievement of good students' performance in examinations (Adu, Tadu \& Eze, 2012; Protheroe, 2008). According to Bandura (1989), there is a triadic relationship among personal factors such as marital status, environmental factors such as the teaching profession and behavioral characteristics such as self-efficacy. Islahi and Nasreen (2013) study found that the influence of marital status on teachers' effectiveness was significantly different between the married and unmarried teachers. On the other hand, Tschannen-Moran and Hoy (2001) identified the domains of teachers' self-efficacy as self-efficacy in student engagement, instructional strategies and classroom management through the Teachers' Self-Efficacy Scale (TSES). Eslami and Fatahi (2008) study found that teachers' selfefficacy had significant influence on the instructional strategies they used in class. However, Yılmaz and Çavaş (2008) study reported a change in teachers' self-efficacy in classroom management with time without considering whether the teacher had changed marital status over that period.

Studies in Africa on the same have been descriptive in nature and have scanty information on the influence of marital status on teachers' self-efficacy (Alao, 2014; DeJaeghere, Williams \& Kyeyune, 2009; Savolainen, Engelbrecht, Nel \& Malinen, 2012; Zinn, 2013). Alao (2014) study was on female teachers in primary and secondary schools in southwestern Nigeria, but DeJaeghere et al. (2009) study found that head teachers had low self-efficacies in specific aspects of their work. Savolainen et al. (2012) and Zinn (2013) focused on teachers' self-efficacy on inclusive education and teachers' information literacy self-efficacy among teachers in South Africa. All these studies, however, noted the importance of teachers' marital status but they did not consider the influence of marital status on teachers' self-efficacy. 
In Kisumu County, Kenya, although some studies on teachers' self-efficacy considered the influence of other variables considered on teachers' self-efficacy, none considered the influence of marital status (Aurah \& McConnell, 2014; Bagaka's, 2011; Kinyua \& Oboko, 2013; Onderi \& Croll, 2009). Aurah and McConnell (2014), Kinyua and Oboko (2013) and Bagaka's (2011) examined the influence of gender and not marital status on teachers' self-efficacy. Onderi and Croll (2009), on the other hand, investigated teachers' self-efficacy and its dimensional correlates in secondary schools in Gucha District, Kenya. Therefore, there was need for a study into the influence of marital status on the selfefficacy of teachers in Kisumu County of Kenya.

\section{Theoretical Framework and Literature Review}

\subsection{Theoretical Framework}

The current study was guided by Bandura's (1989) social cognitive theory. The theory adopts a triadic reciprocal determinism where people influence and are influenced by their environment through self-directed goal tendency (Bandura, 2005). Bandura $(1989 ;$ 1994) and (BUSPH, 2013) defined self-efficacy as persons' beliefs about their capabilities to perform a behavior successfully. Teachers' self-efficacy, therefore, is the teachers' beliefs in their personal capability to motivate and promote learning effectively (Bandura, 1993). The domains of teachers' self-efficacy according to Tschannen-Moran and Hoy (2001) are self-efficacy in instructional strategies, student engagement and classroom management. Instructional strategies are techniques that motivate students to focus their attention in organizing information for effective learning, student engagement is the ability of the teacher to encourage students to learn and classroom management is how teachers create an environment that supports and facilitates both learning (Alberta Learning, 2002; Moalosi, 2012; Oliver, Wehby \& Daniel, 2011). Consequently, teacher self-efficacy in instructional strategies means the teacher's self-beliefs in their capability to be innovative techniques that promote learning among students, self-efficacy in student engagement refers to the teacher's self-beliefs about their capability to motivate students to learn and self-efficacy in classroom management means teachers' self-beliefs in their capability to achieve learning through the learning set-up. The theory informed the present study in that it posited that behavior is a product of the triadic reciprocal determinism of personal factors such as marital status, cognition such as self-efficacy and environment such as the school.

\subsection{Literature Review}

The current study sought data on marital status based on never married, separated, divorced, widowed or married. Holzberger, Philipp and Kunter (2013) study was on the influence of teachers' self-efficacy and instructional quality in a longitudinal panel study. Data was collected from a sample of 155 German secondary mathematics teachers and 3,483 Grade 9 students. The findings indicated that, self-efficacy is both a cause and a consequence of educational processes. The study recommended that future research on teachers' self-efficacy should identify possible mediator variables. The reviewed study only collected quantitative data and not qualitative data and lacked the richness of insight that a qualitative data would have provided, that the present study provided. Amstad, Meier, Fasel, Elfering and Semmer (2011) investigated conducted a secondary research on work-family conflict with Caucasian Americans most of whom were married. The study found that work-family conflict had significant relationship with work-related outcomes. However, the study was a secondary research with Caucasian Americans work-family conflict that were mostly married and not primary research with Kenyan teachers' self-efficacy who are of different marital status.

Another study on Americans by Schoenborn (2004) indicated that married adults are healthier than unmarried adults are. However, the study collected data from American adults on health using Computer-Assisted Personal Interviews (CAPI) and not Kenyan teachers on self-efficacy using both interviews and questionnaires. Consequently, Islahi and Nasreen (2013) study revealed that there were negative significant differences in effectiveness between unmarried and married male teachers only. However, the study was on Indian teachers and not Kenyan teachers. In addition, the study used only quantitative approach and left out qualitative approach, which could have enriched the findings. The influence of type of family on the self-efficacy of adolescents in India was investigated using a sample of adolescents selected through convenient sampling from joint and nuclear families (Singh \& Udainiya, 2009). The study found a significant influence of type of family on self-efficacy where adolescents belonging to joint families were found to be higher than nuclear families on the initiative and persistence dimensions of self-efficacy.

In Africa, Buabeng-Andoh (2012) study found that lack of teacher self-efficacy in Information and Computer Technology (ICT) negatively affected the teaching of ICT in schools. However, the findings were based on secondary 
data and not primary data. This compromised their external validity and may have led to amplification of errors from the primary research. A study done in Nigeria by Adio and Popoola (2010) showed that there was a statistically significant relationship between marital status and self-efficacy. Hence, those who were married had higher levels of self-efficacy than those who were not. However, the reviewed study was a quantitative in nature using Nigerian librarians unlike the present study which focused on the Kenyan teachers. Akintayo (2010) in Nigeria revealed that a significant difference exists between married and single respondents' experience of work-family role conflict. However, the study reviewed above was limited to Nigerian industrial workers, and not Kenyan teachers.

Wafula (2010) study in South Africa showed no correlations between work-family conflict and role salience. However, the study only investigated South African female teachers and not Kenyan teachers. Njoka (2007) study in Embu, Kenya, on the other hand, found that there were no significant differences on Kenyan counselling teachers' selfefficacies based on marital status. Nginah (2012) study in Machakos, Kenya established that marital status influences work family conflict with 75 percent of married teachers experiencing more work family conflict than single, divorced and separated teachers did.

The first domain investigated for influence of marital status was teachers' self-efficacy in classroom management. Tyagi (2013) study, however, revealed that unmarried teachers have higher level of classroom management than married teachers did. Nevertheless, the study was conducted with Indian teachers and not Kenyan teachers. Married and unmarried people display different kinds of polices when they manage people. Roussanov and Savor (2013) study found differences in the management styles of married and unmarried managers in favor of single managers. Nevertheless, the study was a pure qualitative study conducted with US managers and not a mixed methods study conducted on Kenyan teachers. It therefore lacked the quantitative aspect that the current study possesses. On the other hand, conflict at home was found to have an influence on students' self-efficacy. Parsa, Yaacob, Redzuanb, Parsa and Parsa (2014) study in Iran indicated that low inter-parental conflict had positive significant correlation with high students' self-efficacy, while high inter-parental conflict had negative correlation with low self-efficacy. However, the study was carried out among Iranian students and not Kenyan teachers' self-efficacy, as was the current study.

The second domain of teachers' self-efficacy investigated for influence of marital status was teachers' self-efficacy in instructional strategy. The influence of a person's marital status on their teacher self-efficacy in instructional strategy has not received much analytic attention. Kanazawa and Still (2000) study indicated that, while men in general are less likely to be divorced than women, and secondary school teachers in general are less likely to be divorced than others, simultaneously being male and being a secondary school teacher statistically increases the likelihood of being divorced. The study by Kanazawa and Still (2000) revealed that personal factors such as cognition strongly affected marital status. However, the study was on the influence of work on teachers' marital status and not the influence of marital status on teachers' self-efficacy in instructional strategy. In addition, Gao (2012) added that personal factors such as cognition strongly affected marital status. However, the study was on Chinese unmarried attitudes on mate preferences and not influence of marital status on Kenyan teachers' self-efficacy in instructional strategy. Moreover, Bello (2011) study in Nigeria revealed that specific instructional strategies improved the performance of students. However, the study used Nigerian students' and not on Kenyan teachers as with the current study.

The third domain that was investigated for marital influence was teachers' self-efficacy in instructional engagement. Chaturvedi and Purushothaman (2009) study revealed that marital status was a significant determinant of stress-coping. However, the study was conducted on Indian female and not male teachers. The present study filled the gap in literature by including both genders. Interactions between teachers and students in student engagement are fundamental in the educational process (Pianta, Hamre \& Allen, 2012). Pianta et al. (2012) argued that supporting teachers' interactions increases student engagement in the US. They further posited that student engagement is a mediator of impacts that teachers have on student outcomes. In addition, Harbour, Evanovich, Sweigart and Hughes (2015) pointed out that the practices for student engagement include modeling desired behavior, providing opportunities to respond to curricular content and providing feedback. However, the study was a secondary research on student engagement in the US and not a study on teachers' self-efficacy in student engagement in Kenya. Finally, a study in Kirinyaga, Kenya by Munini (2010) found that fathers' absence and risk protective factors influenced pre-school child's performance negatively. However, the reviewed study investigated parents of pre-school children and not secondary school teachers' as was the present study.

\subsection{Goal of the Study}

The goal of the study was to investigate the influence of marital status on the self-efficacy of teachers in Kisumu County of Kenya. 


\section{Research Methodology}

\subsection{Research Design}

The study employed a Concurrent Triangulation Design. This was because Concurrent Triangulation Design leads to convergent validation enables the validation by minimizing biases and increases analytic density (Fielding, 2012; Guion, Diehl \& McDonald, 2011; Yeasmin \& Rahman, 2012). Concurrent triangulation design combined quantitative and qualitative methods through use of questionnaire and interview respectively in data collection on teachers' self-efficacy (Guion et al., 2011; Yeasmin \& Rahman, 2012). Concurrent triangulation design involved the use of different methods and sources to ensure the integrity of data or extend inferences drawn from the data through convergence of both the data and the conclusions derived from the data (Ritchie, 2003). The methods involved collecting data using both questionnaire and interview schedule and the respondents were selected stratified random and purposive sampling receptively.

\subsection{Study Participants}

The target population of the study was 1790 secondary school teachers in public secondary schools in Kisumu County (TSC, 2014). There were 143 public secondary schools in Kisumu County, of which 2 were National, 20 were County and 121 sub-county secondary schools. The population of teachers in national schools was 101 of which 20 were sampled while the population of teachers in County schools was 515 of which 95 were sampled. The population of teachers in Sub-County schools was 1174 of which 212 were sampled. Therefore, the total sample for the study was 327 teachers.

\subsection{Research Instruments}

The instruments for collecting quantitative data were questionnaire while qualitative data was collected using interview schedule. Demographic information was collected using a profile that included gender, marital status, age, teaching experience and job group status. This study adopted the longer form of the Teacher Self-Efficacy Scale (TSES). Tschannen-Moran and Hoy (2001) developed the TSES to measure teachers' self-efficacy and its sub-constructs. This study used a semi-structured interview schedule because of the focus and freedom it accords the researcher in data collection (McKenzie \& Hannan, 2007; Turner, 2010). The current study employed semi-structured interview schedule to conduct in-depth interviewing on teacher self-efficacy.

\subsection{Data Collection Procedures}

The researcher obtained a letter authorizing the use of the Teachers' Self-Efficacy Scale from its author, which allowed the use of the instrument for data collection. Thereafter, the researcher obtained a letter from Board of Post-Graduate Studies (BPGS) of Jaramogi Oginga Odinga University of Science and Technology (JOOUST) to take to the National Council for Science, Technology and Innovation (NACOSTI). The researcher then obtained research permit from NACOSTI to collect data.

Thereafter, notification letters attached to copies of research permit were sent to the County Director of Education (CDE), Kisumu County; the Assistant Deputy Director of Education (ADD) of the sub-counties; and to principals of the sampled schools. The researcher personally visited the schools, met the principals and informed them of the nature and purpose of the research. Thereafter dates for data collection were set. Finally, on the dates agreed, the researcher visited the concerned schools to collect data from the sampled teachers.

The data collection procedures were systematic, ethical and rigorous to collect quality data. The participants were debriefed before administration of the questionnaires. Debriefing involves explaining in some detail the purposes and procedures of the research (Taylor, Peplau \& Sears, 2006). Thereafter, the respondents were given the consent form to fill before the questionnaire was administered. The quantitative data was collected through self-report questionnaire that consisted of two sections of demographic variables and teacher self-efficacy scale. The researcher administered the questionnaire personally to the respondents and waited as the respondents filled them. Thereafter, the filled questionnaires were screened and then filed. Each questionnaire took between $10-20$ minutes to administer.

Qualitative data was collected through interview schedule and the interviews were audio-recorded using a digital voice recorder. The researcher conducted the interviews, each of which lasted between $25-60$ minutes. The interviews 
were held at the participants' places of convenience such as work place and homes. The average length of the interviews was 35 minutes where the shortest interview length was 24 minutes and the longest interview length was 50 minutes.

\subsection{Data Analysis}

The data was analyzed both quantitatively and qualitatively using statistical procedures and thematic analysis respectively. Quantitative data on teachers' self-efficacy was determined by computing the unweighted means of the TSES items. Data was analysis for inferential and descriptive statistics used both Statistical Package for Social Sciences (SPSS) version 22 and Microsoft Excel. The hypotheses were tested at the 95\% level of confidence. The null hypotheses were tested and if the $p$-value obtained was less than 0.05 , then the null hypothesis was rejected. However, if the $p$-value obtained was greater than 0.05 , then the null hypothesis was accepted. The hypotheses were tested using Multivariate Analysis of Variance (MANOVA).

Qualitative data was analyzed using thematic analysis. Thematic analysis is a method for identifying, analyzing and reporting patterns, called themes, within data by organizing and describing the data set in rich detail (Braun \& Clarke, 2006). Interviews from the interviewees were tape-recorded, transcribed, interpreted, themes and sub-themes emerged and coded as in Raburu (2011). Thematic analysis was performed using the five phases of Braun and Clarke (2006), which were, verbatim transcription, initial coding, searching for themes, reviewing themes, defining and naming the themes.

\section{Findings and Discussion}

The study sought to determine the influence of marital status on teachers' self-efficacy and its domains of student engagement, classroom management and instructional strategy. It was hypothesized marital status would not be systematically related to a teachers' self-efficacy. The categories of marital status were never married, separated, divorced, widowed and married. A MANOVA test was performed on teachers' self-efficacy across marital status to yield the results given in the following tables.

Table 1 shows the descriptive statistics of the analysis of the influence of marital status on teachers' self-efficacy.

Table 1: Descriptive Statistics for Marital Status and Teachers' Self-Efficacy

\begin{tabular}{llccc}
\hline & Marital Status & N & Mean & S.D. \\
\hline Teachers' Self-Efficacy in Student Engagement & Never Married & 29 & 34.45 & 2.613 \\
& Separated & 3 & 35.67 & 3.215 \\
& Divorced & 1 & 32.00 &. \\
& Widowed & 13 & 33.69 & 2.985 \\
& Married & 281 & 33.61 & 2.899 \\
& Total & 327 & 33.70 & 2.880 \\
Teachers' Self-Efficacy in Classroom Management & Never Married & 29 & 33.79 & 3.288 \\
& Separated & 3 & 34.33 & 4.726 \\
& Divorced & 1 & 36.00 &. \\
& Widowed & 13 & 32.77 & 2.713 \\
& Married & 281 & 33.97 & 3.280 \\
& Total & 327 & 33.91 & 3.263 \\
& Never Married & 29 & 34.97 & 2.86 \\
& Separated & 3 & 35.00 & 2.000 \\
& Divorced & 1 & 32.00 &. \\
& Widowed & 13 & 31.92 & 2.465 \\
& Married & 281 & 34.23 & 2.993 \\
& Total & 327 & 34.21 & 2.988 \\
\hline
\end{tabular}

The results given in Table 1 shows that while the married group had the largest number of respondents $(\mathrm{N}=281)$, the divorced was the group with the lowest frequency $(\mathrm{N}=1)$. The table also shows the descriptive statistics for teachers' selfefficacy in student engagement $(M=33.7 ; S D=2.88)$, classroom management $(M=33.9 ; S D=3.26)$ and instructional strategy $(\mathrm{M}=34.2 ; \mathrm{SD}=2.99)$.

These differences in descriptive results were tested for significant differences using MANOVA tests involving Wilk's 
$\lambda$. The results are presented in Table 2.

Table 2: Multivariate tests for Effect of Marital Status on Teachers' Self-Efficacy

\begin{tabular}{clcccccccc}
\hline Effect & & Value & $F$ & Hypothesis df & Error df & Sig & Partial eta ${ }^{2}$ & $\begin{array}{c}\text { Noncent. } \\
\text { parameter }\end{array}$ & $\begin{array}{c}\text { Observed } \\
\text { power }\end{array}$ \\
\hline Marital Status & Pillai's Trace & .050 & 1.358 & 12.000 & 966.000 & .180 & .017 & 16.296 & .763 \\
& Wilk's Lambda & .951 & 1.358 & 12.000 & 846.932 & .181 & .017 & 14.356 & .693 \\
& Hotelling's Trace & .051 & 1.357 & 12.000 & 956.000 & .181 & .017 & 16.282 & .792 \\
& Roy's Largest Root & .034 & 2.703 & 4.000 & 322.000 & .031 & .032 & 10.812 & .747 \\
\hline
\end{tabular}

Computed using alpha $=0.05$

MANOVA results from the Table 2 demonstrated that the influence of marital status on teachers' self-efficacy was not significant, Wilk's $\lambda(4,322)=0.951, p=0.181$. Therefore, the differences in teachers' self-efficacies across different marital statuses were not statistically significant. This finding was in similar to the findings of Wafula (2010), Njoka (2007) and Nginah (2012) who found that the influence of marital status on teachers' self-efficacy was not significant. It was contrary to those study findings that reported that there was a significant influence of marital status on teachers' selfefficacy in favor of the married teachers (Adio \& Popola, 2010; Islahi \& Nasreen, 2013; Schoenborn, 2004; Singh \& Udainya, 2009). It was also contrary to those study findings that indicated that there was a significant influence of marital status on teachers' self-efficacy in favor of the single (Akintayo, 2010; Amstad et al., 2011; Tyagi, 2013).

Furthermore, the results from the MANOVA tests were taken through univariate tests to determine betweensubjects effects of marital status on the domains of teachers' self-efficacy. The domains of teachers' self-efficacy are selfefficacy in student engagement, instructional strategies and classroom management. The results of the univariate tests are captured in Table 3.

Table 3: Between-Subjects Effects of Marital Status on Teachers' Self-Efficacy

\begin{tabular}{llcccc}
\hline Source & Dependent variable & df & $F$ & Sig & Observed Power \\
\hline \multirow{2}{*}{ Marital Status } & Self-efficacy in Student Engagement & 4 & 0.991 & .412 & .313 \\
& Self-efficacy in Instructional Strategy & 4 & 2.613 & .035 & .730 \\
& Self-efficacy in Classroom Management & 4 & 0.541 & .706 & .181 \\
\hline
\end{tabular}

Computed using alpha $=0.05$

The data in Table 3 show the univariate results for the relationship between marital status and the domains of teachers' self-efficacy. Univariate results demonstrated significant influence of marital status on teachers' self-efficacy in instructional strategy, $F(4,322)=2.613, p=0.035$. This was similar to the findings of Bello (2011), Chaturvedi and Purushothaman (2009) and Pianta et al. (2012) who had found a significant influence of marital status on teachers' selfefficacy in instructional strategies in favor of the married teachers. Nevertheless, post hoc tests were not performed to establish the nature of the influence marital status on teachers' self-efficacy in instructional strategies because one group, that is, the divorced teachers, had only one case. This did not meet the condition for post hoc tests that each dependent variable should have at least two cases.

However, there were no significant influence of marital status on teachers' self-efficacy in teachers' self-efficacy in student engagement, $F(4,322)=0.991, p=0.412$. This finding was contrary to Kanazawa and Still (2000) and Gao (2012) who had reported significant influence of marital status on teachers' self-efficacy in student engagement in favor of the single and married teachers respectively. There were, moreover, non-significant influence of marital status on teachers' self-efficacy in teachers' self-efficacy in classroom management, $F(4,322)=0.541, p=0.706$. This finding was contrary to Parsa et al (2014) and Roussanov and Savor (2013) who had found significant influence of marital status on teachers' self-efficacy in classroom management in favor of single teachers.

Data from interviews indicated that most of the respondents felt that marital status had an influence on teacher self-efficacy. Most teachers said that marital status influences teachers' self-efficacy with married teachers having higher self-efficacy than unmarried teachers due to increase in motherliness and fatherliness among married teachers. Some teacher respondents said, "Students have confidence in you and confide in you as a mother. The single are rough and unapproachable" (Teacher 12) and, You become better... You begin to see what a father really means. This is somebody's daughter (Teacher 3). Another reason given for this was that single teachers were perceived as more ambitious than the married teachers were. Therefore, the single teachers quickly get frustrated when they do not get the 
recognition they want for their work. For example, a teacher respondent said that:

The married male teacher delivers more quality than the unmarried does. The expectations of the single are frustrated when they begin teaching and they want recognition hence pressurize students more. Singles are more goaloriented (Teacher, 9).

The finding of the current study that marital status influenced teachers' self-efficacy with the married having higher self-efficacy was similar to findings by Adio and Popola (2010), Islahi and Nasreen (2013), Schoenborn (2004) and Singh and Udainya (2009) that reported that there was a significant influence of marital status on teachers' self-efficacy in favor of the married teachers. However, it was contrary to the findings of Wafula (2010), Njoka (2007) and Nginah (2012) who found that the influence of marital status on teachers' self-efficacy was not significant. It was also contrary to findings by Akintayo (2010), Amstad et al. (2011) and Tyagi (2013) that indicated that there was a significant influence of marital status on teachers' self-efficacy in favor of the single.

Nevertheless, some teachers felt that single teachers had a higher teacher-self-efficacy than married teachers did. For example, some teacher respondents said, "The single are better because they are always there for the students but the married will be committed with family affairs" (Teacher 11) and, "With its problems marriage sometimes interferers for the worse" (Teacher 4). This finding was similar to the findings of Akintayo (2010), Amstad et al. (2011) and Tyagi (2013) that indicated that there was a significant influence of marital status on teachers' self-efficacy in favor of the single. It was contrary to the findings of Adio and Popola (2010), Islahi and Nasreen (2013), Nginah (2012), Njoka (2007), Schoenborn (2004), Singh and Udainya (2009) and Wafula (2010) that found in favor of the married and those that found that there was no influence.

However, some teachers said marital status did not influence teachers' self-efficacy. The reason the teacher gave for the response was that in their school, work was allocated similarly between the married and the single and hence teachers worked similarly. A teacher respondent said, "There is no difference at all between the married and unmarried because work is allocated similarly" (Teacher 2). This finding was similar to those of Wafula (2010), Njoka (2007) and Nginah (2012) who had reported that there was no significant influence of marital status on teachers' self-efficacy. It was however, contrary to findings by Adio and Popola (2010), Akintayo (2010), Amstad et al. (2011), Islahi and Nasreen (2013), Schoenborn (2004), Singh and Udainya (2009) and Tyagi (2013) that had indicated that there was a significant influence of marital status on teachers' self-efficacy.

Most of the respondents said that marriage improved the teachers' self-efficacy in classroom management. This was because the married were seen as emotionally stable, having children makes the teacher more tolerant and the married female teachers were not harsh with the female students as rivals. For instance, a teacher respondent said, "The single female teachers are worse in managing students in learning because they see the female students as fellow women and rivals" (Teacher 4). The finding of the current study was contrary to Parsa et al. (2014), Roussanov and Savor (2013) and Tyagi (2013) that had reported that marital status influenced teachers' self-efficacy in classroom management in favor of the single teachers.

Most of the respondents felt that marital status influenced teachers' self-efficacy in student engagement in favor of the married teachers. For instance a teacher respondent said, "Having children, for the married female teachers, mellows up the teacher and they engage the students better than the female unmarried does (Teacher 9). This finding was similar to Harbour et al. (2015), Munini (2010) and Pianta et al. (2012) that had reported that marital status influenced teachers' self-efficacy in classroom management in favor of the married but was contrary to Chaturvedi and Purushothaman (2009) that had reported that marital status influenced teachers' self-efficacy in favor of the single teachers.

Most respondents reported that marital status influenced teachers' self-efficacy in instructional strategies in favor of the married because the married are emotionally stable. Hence, a teacher respondent said, "The divorced are very harsh until students fear them when they are teaching (Teacher 6). Furthermore, a teacher respondent said, "The single female teachers have their stress of feeling life is unfair; they want to hit out at life and are very pessimistic towards the students" (Teacher 12). The psycho-emotional problems that single teachers have may be due to the societal stigmatization of not being married, according to Raburu (2011). This finding was contrary to those of Kanazawa and Still (2010) and Gao (2012) who had reported that the married teachers have lower self-efficacies than the single ones did.

Other teachers, however, argued that single teachers have higher teacher self-efficacy in instructional strategies than married teachers did. A reason given for this was that married teachers sympathize with the students and therefore, they cannot use high-pressure instructional strategies that improve the performance of the students. For instance, a respondent teacher said, "Sometimes we have to put a lot of pressure, the married teachers sympathizes. They ask, 'Would you want your child to be treated like that"' (Teacher 2). Another reason given by some respondents why single teachers have higher self-efficacy in instructional strategies than married ones was that domestic commitments made the 
married teacher to have lower self-efficacy in instructional strategies. Some teacher respondents reported that, "The single are better because they are always there for the students but the married will be committed with family affairs" (Teacher 7), and "Female teachers who have families have more stress and work at home. Therefore, they work less in instructional strategies" (Teacher 5). This finding was similar to those of Kanazawa and Still (2010) and Gao (2012) who had reported that the married teachers have lower self-efficacies than the single ones did.

The quantitative findings of the current study, therefore, indicated that there was no significant influence of marital status on teachers' self-efficacy at the $p<.05$ level for the five conditions of marital status. This indicated that the level of teachers' self-efficacy was not significantly different between teachers of different marital statuses. Moreover, there was no significant influence of marital status on teachers' self-efficacy in student engagement and classroom management. On the other hand, there was a significant influence of marital status on teachers' self-efficacy in instructional strategies.

In the qualitative findings, most of the respondents indicated that marital status had an influence on teacher selfefficacy. While some teachers said that single teachers had a higher teacher self-efficacy than married teachers did, others said that married teachers have higher teacher self-efficacy than single teachers. However, one teacher said marital status was not a factor. In addition, the teachers indicated that married teachers had higher teacher self-efficacy in student engagement and classroom management than unmarried teachers had. However, the teachers reported that single female teachers had higher teachers' self-efficacy than married female teachers had in instructional strategies.

\section{Concluding Remarks}

This study, therefore, concludes that male and married teachers attempt to do more things in the school, put more effort in their work, persevere longer in their duties and recover faster when they fail to meet set targets such as school mean. This is because, according to Adu et al. (2012), Klassen and Chiu (2010) and Protheroe (2008), teachers with high selfefficacy are better in planning, innovation, resilience and persistence to achieve set objectives. Therefore, male and married teachers may be concluded to work harder and longer to attain set targets because they have higher selfefficacies than female and unmarried teachers have respectively.

\section{References}

Akram, B. \& Ghazanfar, L. (2014). Self-efficacy and academic performance of the students of Gujarat University, Pakistan. Academic Research International, Vol. 5 No. 1: 283 - 290.

Aktaş, M., Kurt, H., Aksu, Ö. \& Ekic, G. (2013). Gender and experience as predictor of biology teachers' education process self-efficacy perception and perception of responsibility from student success. International Journal on New Trends in Education and Their Implications, Volume 4, Issue 3: 37 - 47.

Alao, I. (2014). Teacher effectiveness among female teachers in primary and secondary schools in southwestern Nigeria. Journal of Educational Leadership in Action. Retrieved on $4^{\text {th }}$ June 2015 from http://www.lindenwood.edu/ela/issue02/alao.html

Alberta Learning (2002). Health and Life Skills Guide to Implementation (K-9): Instructional Strategies. Retrieved on $6^{\text {th }}$ June 2015 from https://education.alberta.ca/media/352984/is.pdf

Al-Zu'bi, Z. H. (2013). Classroom management problems among teacher students training at Hashemite University. European Journal of Business and Social Sciences, Vol. 2, No. 3: $140-149$.

American Psychological Association (APA, 2011). The guidelines for psychological practice with lesbian, gay and bisexual clients. Retrieved on $24^{\text {th }}$ April 2014 from http://www.apa.org/pi/lgbt/resources/guidelines.aspx

Andersen, L. B. (2011). Teacher diversity: Do male and female teachers have different self-efficacy and job satisfaction? European Group for Public Administration (EGPA). Retrieved on 3rd February 2015 from https://soc.kuleuven.be/io/egpa/HRM/bucharest/ Andersen2011.pdf

Arslan, A. (2013). Investigation of Relationship between Sources of Self-efficacy Beliefs of Secondary School Students and Some Variables. Educational Sciences: Theory \& Practice - 13(4): 1983 - 1993.

Aslan, O. (2009). The Role of Gender and Language Learning Strategies in Learning English. Unpublished Thesis. Department of English Language Teaching, Middle East Technical University.

Amstad, F. T., Meier, L. L., Fasel, U., Elfering, A. \& Semmer, N. K. (2011). A meta-analysis of work-family conflict and various outcomes. Journal of Occupational Health Psychology, Vol. 16, No. 2: 151 -156.

Aurah, C. \& McConnell, T. (2014). Comparative study on pre-service science teachers' self-efficacy beliefs of teaching in Kenya and the United States of America; USA. American Journal of Educational Research, 2014, Vol. 2, No. 4, pp. 233 - 239.

Bagaka's, J. (2011). The role of teacher characteristics and practices on upper secondary school students' mathematics self-efficacy in Nyanza Province of Kenya: A multilevel analysis. International Journal of Science and Mathematics Education, Volume 9, Issue 4: $817-842$.

Bandura, A. (1967). Relative efficacy of self-monitored and externally imposed reinforcement systems. Journal of Personality and Social Psychology, Volume 7, Number 2: $111-116$. 
Bandura, A. (1989). Social cognitive theory. In R. Vasta (Ed.), Annals of child Development, Vol. 6. pp. 1 - 60. Greenwich, CT: JAl Press.

Bandura, A. (1993). Perceived self-efficacy in cognitive development and functioning. Educational Psychology, volume 28 (2): 117 - 148. Bandura, A. (1994). Self-efficacy. In V. S. Ramachaudran (Ed.), Encyclopedia of Human Behavior, Volume 4, 71 - 81.

Bandura, A. (2001). Social Cognitive Theory: An Agentic Perspective. Annual Review of Psychology, Volume 52, 1 - 26.

Bandura, A. (2005). The evolution of social cognitive theory. In K. G. Smith and M. A. Hitt (Eds). Great Minds in management (pp. 9 35). Oxford: Oxford University Press.

Bello, T. O. (2011). Effect of group instructional strategy on students' performance in selected physics concepts. The African Symposium, Volume 11, №. 1: $71-79$.

Bilali, O. (2013). Teaching efficacy to student teachers in the faculty of education, Elbasan, Albania. Journal of Educational and Social Research, Volume 3 (1), pp. 179 - 185.

Braun, V. \& Clarke, V. (2006). Using thematic analysis in psychology. Qualitative Research in Psychology, Volume 3, Number 2: 77 101.

Buabeng-Andoh, C. (2012). Factors influencing teachers' adoption and integration of information and communication technology into teaching: A review of the literature. International Journal of Education and Development using Information and Communication Technology, 2012, Vol. 8, Issue 1, pp. 136-155.

Boston University School of Public Health (BUSPH, 2013). The Social Cognitive Theory. Behavioral Change Models. Retrieved on 3 rd January 2015 from http://sphweb.bumc.bu.edu/ott//MPH-Modules/SB/SB721-Models/SB721-Models5.html

Butucha, K. (2013). Gender and school type differences in self-efficacy in teaching. Sky Journal of Educational Research Vol. 1(4): 23 31.

Butucha, K. (2014). Relationships between secondary school beginning teachers' perceptions of self-efficacy and professional commitment in Ethiopia. International Journal of Academic Research in Progressive Education and Development, Vol. 3, No. 3 (Special Issue), pp. $79-104$.

Chaturvedi, M. \& Purushothaman, T. (2009). Coping behaviour of female teachers: Demographic determinants. Industrial Psychiatry Journal, 18(1): 36 - 38. doi: 10.4103/0972-6748.57856

Creswell, J. W. (2008). Research design: Qualitative, quantitative and mixed Methods approaches. Retrieved on May 7, 2014 from http://www.sagepub.com/upm-data/22780_Chapter_1.pdf

DeJaeghere, J. G., Williams, R. \& Kyeyune, R. (2009). Ügandan secondary school headteachers' efficacy: What kind of training for whom? International Journal of Educational Development, 29, pp. 312 - 320.

Eslami, Z. R. \& Fatahi, A. (2008). Teachers' sense of self-efficacy, English proficiency and instructional strategies: A study of nonnative EFL teachers in Iran. Retrieved on May 5, 2015 from http://tesl-ej.org/ej44/a1.pdf

Fielding, N. G. (2012). Triangulation and Mixed Methods Designs: Data Integration with New Research Technologies. Journal of Mixed Methods Research, Vol. 6, №. 2: $124-136$.

Gao, C. (2012). A Study of the Effects of the Unmarried Teachers' Marriage Attitude on Mate Preferences in Ping Tung County. Published Master's Thesis. Retrieved on $6^{\text {th }}$ June 2015 from http://140.127.82.35/ETD-db/ETD-search/view_etd?URN=etd0618112-171432

Guion, L. A., Diehl, D. C. \& McDonald, D. (2011). Conducting an in-depth interview. FCS6012. Department of Family, Youth and Community Sciences, University of Florida.

Harbour, K. E., Evanovich, L. L., Sweigart, C. A. \& Hughes, L. E. (2015). A brief review of effective teaching practices that maximize student engagement. Preventing School Failure: Alternative Education for Children and Youth, Volume 59, Issue 1: 5- 13.

Holzberger, D., Philipp, A. \& Kunter, M. (2013). How Teachers' Self-Efficacy Is Related to Instructional Quality: A Longitudinal Analysis. Journal of Educational Psychology, Vol. 105, №. 3, $774-786$.

Islahi, F. \& Nasreen, D. (2013). Who make effective teachers, men or women? An Indian perspective. Universal Journal of Educational Research, 1(4): $285-293$.

Kanazawa, S. \& Still, M. C. (2000). Teaching may be hazardous to your marriage. Evolution and Human Behavior, Volume 21: 185 190.

Kinyua, M. \& Oboko, R. (2013). Impact of teacher's gender in imparting 21st competencies: Internal barriers in Kenya secondary schools. Research Project Report. School of Computing and Informatics, University of Nairobi.

Klassen, R. M. \& Chiu, M. M. (2010). Effects on teachers' self-efficacy and job satisfaction: Teacher gender, years of experience and job stress. Journal of Educational Psychology, 2010, Volume 102, Number 3: 741-756.

Mackay, J. \& Parkinson, J. (2010). Gender, self-efficacy and achievement among South African technology teacher trainees. Gender and Education, Volume 22, Issue 1: 87 - 103.

McKenzie, L. \& Hannan, A. (2007). What are the advantages and disadvantages of interviews?

Interviews in Education Research. Retrieved on 10th October, 2013 from www.edu.plymouth.ac.uk/resined/interviews/inthome.htm\#A. Introduction

Moalosi, W. T. S. (2012). Teacher Efficacy: Is Student Engagement Essential in Botswana Junior Secondary Schools? International Journal of Scientific Research in Education, 5(3), 207 - 213.

Munini, S. E. (2010). Influence of single parenthood on pre-school children's academic performance in Kirinyaga District: A case study of Mwea Division. Unpublished Thesis. Department of Educational Communication and Technology. University of Nairobi.

Nginah, M. N. (2012). Influence of work-family conflicts on secondary school teachers' level of job satisfaction in Machakos District, 
Kenya. Unpublished Thesis. Department of Educational Administration, University of Nairobi.

Njoka, E. (2007). Guiding and Counselling Pupils in Kenyan Public Primary Schools: Head Teachers and Teacher Counsellors Role Perceptions and Experiences. Published Doctoral Thesis. Durham University.

Oliver, R., Wehby, J. \& Daniel, J. (2011). Teacher classroom management practices: Effects on disruptive or aggressive student behavior. Campbell Systematic Reviews, Volume 4:1 - 55.

Onderi, H. \& Croll, P. (2009). Teacher self-perceptions of effectiveness: A study in a district of Kenya. Educational Research, Volume 51, Issue 1: $97-107$.

Parsa, N., Yaacob, S. N., Redzuanb, M., Parsa, P. \& Parsa, B. (2014). Effects of inter-parental conflict on college student's self-efficacy in Hamadan, Iran. Procedia - Social and Behavioral Sciences, Volume 152, 7: 241- 245.

Pianta, R. C., Hamre, B. K. \& Allen, J. P. (2012). Teacher-student relationships and engagement: Conceptualizing, measuring and improving the capacity of classroom interactions. In S.L. Christenson et al. (eds.), Handbook of Research on Student Engagement, 365 - 386. Springer Science Business Media.

Protheroe, N. (2008). Teacher efficacy: What is it and does it matter? Principal: $42-45$.

Raburu, P. A. (2011). Women academics' careers in Kenya. Unpublished Thesis. Lancaster University, UK.

Roussanov, N. \& Savor, P. (2013). Marriage and managers' attitudes to risk. Retrieved on $4^{\text {th }}$ June 2015 from http://sites.temple.edu/ psavor/files/2013/08/status_managers_draft_2013_12_13.pdf

Savolainen, H., Engelbrecht, P., Nel, M. \& Malinen, O. (2012).Understanding teachers' attitudes and self-efficacy in inclusive education: Implications for pre-service and in-service teacher education. European Journal of Special Needs Education, Volume 27, Number 1, p. $51-68$.

Schoenborn, C. A. (2004). Marital status and health: United States, 1999-2002. Advance Data from Vital and Health Statistics, Number 351. Hyattsville, Maryland: National Center for Health Statistics.

Singh, B. \& Udainiya, R. (2009). Self-Efficacy and Well-Being of Adolescents. Journal of the Indian Academy of Applied Psychology, Vol. 35 , No. 2, $227-232$.

Stough, L. M. \& Montague, M. L. (2014). How teachers learn to be classroom managers. Educational Psychologist, 36:103 - 112.

Teachers' Service Commission (2014). Teachers' Service Commission of Kenya Online Services: Listing of Schools - Kisumu County. Retrieved on May 18, 2014 from www.teachersonline.go.ke/masterbasic.aspx

Tschannen-Moran, M. \& Hoy, W. A. (2001). Teacher Efficacy Scales. Retrieved on 4th March 2014 from http://people.ehe.osu.edu/ahoy/ files/2009/02/tses.pdf

Turner, A. G. (2003). Sampling Frames and Master Samples. Retrieved on May 11, 2014 from http://unstats.un.org/unsd/demographic/ meetings/egm/sampling_1203/docs/no_3.pdf

Tyagi, S. (2013). A Study of Teaching Effectiveness of Secondary School Teachers in Relation to their Demographic Characteristics. International Journal of Engineering and Innovative Technology (IJEIT) Volume 3, Issue 1: 288 - 295.

Wafula, A. N. (2010). Work-family conflict among women from a collectivistic culture. Department of Industrial Psychology, University of the Western Cape.

Yeasmin, S. \& Rahman, K. F. (2012). Triangulation research method as the tool of social science research. Bangladesh University of Professionals (BUP) Journal, Volume 1, Issue 1, pp. $154-163$.

YıImaz, H. \& Çavaş, P. H. (2008). The Effect of the Teaching Practice on Pre-service Elementary Teachers' Science Teaching Efficacy and Classroom Management Beliefs. Eurasia Journal of Mathematics, Science \& Technology Education, Volume 4(1): 45 - 54.

Zinn, S. (2013). The information literacy self-efficacy of disadvantaged teachers in South Africa: Worldwide commonalities and challenges in information literacy research and practice. Communications in Computer and Information Science Volume 397: 212 $-218$. 